\title{
Physical Atributes of a Oxisol from the Brazilian Cerrado under Different Management Systems
}

\author{
Márcio Godofrêdo Rocha Lobato ${ }^{1}$, Fabrício Menezes Telo Sampaio ${ }^{2}$, Júlio César Azevedo Nóbrega ${ }^{3}$, \\ Mozart Martins Ferreira ${ }^{4}$, Sammy Sidney Rocha Matias ${ }^{5}$, Alessandro Franco Torres ${ }^{5}$, Cillas Pollicarto Silva ${ }^{1}$ \\ \& Cleyton Saialy Medeiros Cunha ${ }^{1}$ \\ ${ }^{1}$ Department of Soil Sciences, Federal University of Ceará, Brazil \\ ${ }^{2}$ Federal University Rural of Rio de Janeiro, Brazil \\ ${ }^{3}$ Federal University Recôncavo of Bahia, Brazil \\ ${ }^{4}$ Department of Soil Science, Federal University of Lavras, Brazil \\ ${ }^{5}$ State University of Piauí, Brazil \\ Correspondence: Márcio Godofrêdo Rocha Lobato, Department of Soil Sciences, Federal University of Ceará, \\ Brazil. E-mail: marciogrl@hotmail.com
}

Received: October 22, 2017

doi:10.5539/jas.v10n1p361
Accepted: November 27, 2017 Online Published: December 15, 2017

URL: https://doi.org/10.5539/jas.v10n1p361

\begin{abstract}
The tillage systems induce changes in soil structure; modify the porous space, and influence soil water and air dynamics. In this sense, it is important to evaluate these impacts on soil physical quality according to different tillage system with distinct years of implementation. The physical properties of a Oxisol at the Brazilian Cerrado with distinct tillage conditions (conventional, no-till, and a native Cerrado) with different years were compared. The study was conducted at Novo Horizonte farm, at the Cerrado region of southwest Piauí. Soil samples were collected at $0.0-0.10,0.10-0.20$ and $0.20-0.30 \mathrm{~m}$ depth in different management systems: no-till with three and five years of implantation (NT3 and NT5, respectively); conventional till with five and nine years (CC5 and CC9, respectively); and a native cerrado area. Were analyzed the aggregate stability in water, soil bulk density, particle density, macro and microporosity, total porosity and total organic carbon. The years of implementation of the tillage systems caused changes in the soil physical properties, which were more evident in the surface layer. Although improved soil physical attributes were observed in no-till after five years of implantation, a longer evaluation time is required for the studied conditions.
\end{abstract}

Keywords: conventional tillage, no-tillage, soil aggregate stability, soil physical quality

\section{Introduction}

The Brazilian Cerrado is being highlighted in the agricultural scenario due to the significant increase in grains and fibers cultivation area. However, besides the concern for food production, it is important to point out that the cropping in these areas may affect the soil physical quality.

The tillage practices induce changes in soil physical properties affecting the plant development and, consequently, decreasing the productivity. The impacts can be summarized as changes in the macroporosity (Carneiro et al., 2009; Wendling et al., 2012); aggregates stability (Fontenele et al., 2009; Santos et al., 2012; Servadio et al., 2016); organic matter content (Pragana et al., 2012; Santos et al., 2012); soil-water infiltration, aeration and permeability (Fontana et al., 2016; Farias et al., 2017).

The conventional tillage practices increase macroporosity (Silva et al., 2009), but also induces subsurface compaction. Additionally, plowing affects soil structure breaking the connection between aggregates (Bavoso et al., 2010), contributing to organic matter oxidation (Rossetti \& Centurion, 2015).

Conservation tillage practices, such as no-till, consists of technologies that are used to enhance the sustainability of agricultural systems (Rossetti \& Centurion, 2015). These practices include cover cropping; crop rotation, and lower disturbance (Betioli Junior et al., 2012, Hickmann et al., 2012) which reduce organic matter decomposition (Costa et al., 2009; Pragana et al., 2012; Santos et al., 2012) and improve soil structure quality (Fontenele et al., 2009; Silva et al., 2014a). Despite several studies report that no-till may increase soil bulk 
density and microporosity (Pragana et al., 2012), these effects can be minimized by cover crops (Silva et al., 2014b). In addition, the crop residues on the soil surface reduce erosion, as it promotes the dissipation of the raindrop kinetic energy; and reduces clod disintegration and surface sealing, favoring water infiltration (Ferreira et al., 2010).

The evaluation soil physical quality is performed using many variables, which makes it expensive and time consuming. In this sense, multivariate statistical analysis has been a widely used, since it can explain the maximum interactions among the variables and indicate the most important variables to the objective, e.g., evaluate soil physical quality (Pragana et al., 2012). Considering the effect on the soil structure caused by tillage, we tested the hypothesis that the no-till improves soil physical attributes, and this contribution increases during the time. In this way, this study aimed to evaluate the physical attributes of a Oxisol of the Cerrado at Piauí state under conventional and no-till system, at different ages.

\section{Material and Methods}

The experiment was conducted at Novo Horizonte Farm $\left(09^{\circ} 19^{\prime} 22^{\prime \prime} \mathrm{S}\right.$ and $\left.44^{\circ} 49^{\prime} 55.6^{\prime \prime} \mathrm{W}\right)$, in the Cerrado region of SW-Piauí, located at the Serra do Quilombo. The study site is marked by a warm semi-humid climate, with a $1100 \mathrm{~mm} \mathrm{yr}^{-1}$ mean precipitation, and classified as Aw according to Köppen climatic classification.

The studied soil was classified as a Oxisol with grain size composition presented in Table 1. Soil samples were collected in a conventional till area cultivated during five and nine years, respectively CC5 and CC9; a no-till area with three and five years of implementation, respectively NT3 and NT5; and a native Cerrado (NC).

Table 1. Particle size distribution of studied sites (Native Cerrado; conventional and no-tillage)

\begin{tabular}{lllll}
\hline Manejo & Sand & Clay & Silt & Soil textural class \\
\hline & $----------~_{\text {N kg }}{ }^{-1}$ & ------------- & \\
NT5 & 592 & 320 & 88 & Sandy clay loam \\
NT3 & 592 & 324 & 84 & Sandy clay loam \\
CC9 & 768 & 205 & 27 & Sandy loam \\
CC5 & 738 & 226 & 36 & Sandy loam \\
\hline
\end{tabular}

Both the conventional till sites have been cultivated with soybeans since 2006 and 2002, characterizing CC5 and CC9, respectively. At the no-till area, NT3 was conventionally tilled during four years using 5 tons of limestone $\mathrm{ha}^{-1}$ (2.0 tons during the first year and 1.5 tons in the following two years), fertilized with $300 \mathrm{~kg} \mathrm{ha}^{-1}$ of 00-25-00 NPK $+8 \%$ of S and cover fertilization with $100 \mathrm{~kg} \mathrm{ha}^{-1}$ of KCl for soybean, and $400 \mathrm{~kg} \mathrm{ha}^{-1}$ of the formula $04-20-20+0.5 \%$ of $\mathrm{Zn}$ for rice, being replaced by soybean in 2008. In the 2009/2010 harvest, cultivation of corn intercropped with brachiaria. The NT5 was conventionally maintained for six years and converted to the no-tillage system five years ago with soybean/millet and corn/brachiaria consortia alternately. Before its conversion, $5.0 \mathrm{t}$ of limestone was applied in 2003, $1.5 \mathrm{t}$ in 2004, 2005 and $1.0 \mathrm{t}$ in 2006, incorporated with a grid of $28^{\prime \prime}$.

Soil samples were collected at each site, at $0.0-0.10 ; 0.10-0.20 ; 0.20-0.30 \mathrm{~m}$ depth with five replicates, accounting 75 samples. Aggregates stability was evaluated using wet sieving (Yoder, 1936). Thus, air-dried aggregates $(25 \mathrm{~g})$ were sieved in a $8 \mathrm{~mm}$ mesh and the clods retained in a $4.75 \mathrm{~mm}$ diameter mesh were subjected to slow pre-wetting, by an atomizer using distilled water. The 4.75 to $8 \mathrm{~mm}$ clods were subjected to vertical stirring during 15 minutes in the Yoder apparatus, using sieves with 2.0;1.0;0.50 0.25 and $0.105 \mathrm{~mm}$ diameter mesh. After the 15 minutes, the collected clods were oven dried $\left(105^{\circ} \mathrm{C}\right)$. Geometric Mean Diameter (GMD) of the aggregates was calculated as follows (Equation 1):

$$
G M D=\frac{\sum_{i=1}^{n} w_{i} \log x_{i}}{\sum_{i=1}^{n} w_{i}}
$$

Where, $x_{\mathrm{i}}$ is the mean diameter of each size fraction $(\mathrm{mm}), w_{i}$ is the weight of aggregate in a size class with an average diameter $x_{i}(\mathrm{~g})$ and $\sum_{i=1}^{n} w_{i}$ is the weight of the sample. 
Undisturbed soil samples were collected using a cylindrical metal sampler ( $0.05 \mathrm{~m}$ diameter and height) for the determination of soil bulk density (Bd). Soil particle density (Pd) was assessed using a pycnometer, and soil total porosity $(\mathrm{Tp})$ was calculated according to Equation 2:

$$
T p=\left(1-\frac{B_{d}}{P_{d}}\right) \times 100
$$

Microporosity (Mic) was determined using the Haines funnel, equivalent to water content at $6 \mathrm{kPa}$. The macroporosity (Mac) was determined as the difference between total porosity and microporosity, according to the method described in EMBRAPA (2012). Total organic C (TOC) was quantified in milled and sieved (0.25 $\mathrm{mm}$ ) samples using dry combustion method at $950{ }^{\circ} \mathrm{C}$ (Vario TOC cube, Elementar).

For statistical analysis, the study was conducted in a completely randomized design, using a factorial scheme (systems $\times$ soil depth) with split plots and five replicates. The results were compared using analysis of variance (ANOVA) and Tukey test at 5\% probability. Additionally, multivariate agglomerative hierarchical clustering (AHP) was performed to identify the similarity between cultivation systems, and principal component analysis (PCA) to reduce the number of variables and indicate the importance of each to explain the variance and principal component (PC). Principal components that present eigenvalues above 1 and an accumulated variance above $80 \%$ were selected. For the multivariate statistical analysis was used the XLSTAT demo version (2016). All multivariate analysis were performed after the standardization of the variables, e.g., mean equals 0 and variance equals 1 .

\section{Results and Discussion}

The Native Cerrado area presented the highest GMD $(4.84 \mathrm{~mm}), \mathrm{Tp}\left(0.46 \mathrm{~m}^{3} \mathrm{~m}^{-3}\right)$ and Mac $\left(0.26 \mathrm{~m}^{3} \mathrm{~m}^{-3}\right)$ mean values in all evaluated soil layers. For all studied sites, was recorded lower GMD; Tp; and Mac, associated with higher Bd values, at deeper soil layers. The lower Bd recorded at NT5 $\left(1.36 \mathrm{Mg} \mathrm{m}^{-3}\right)$, compared to other sites, may be related to the higher clay content (Table 2).

Table 2. Total Porosity (Tp), Macroporosity (Mac), Microporosity (Mic), Bulk Density (Bd), Geometric Mean Diameter (GMD) and Total Organic Carbon (TOC) for the studied sites

\begin{tabular}{|c|c|c|c|c|c|c|c|}
\hline Prof. (m) & Manejo & $\mathrm{Tp}$ & Mac & Mic & GMD & TOC & $\mathrm{Bd}$ \\
\hline \multirow{6}{*}{$\begin{array}{l}0 \\
0 \\
0 \\
0 \\
0 \\
0\end{array}$} & & ------------ & $---m^{3} m^{-3}$ & -------------- & $\mathrm{mm}$ & $\mathrm{g} \mathrm{kg}^{-1}$ & $\mathrm{Mg} \mathrm{m}^{-3}$ \\
\hline & $\mathrm{NC}$ & $0.53 \mathrm{Aa}$ & $0.28 \mathrm{Aa}$ & $0.25 \mathrm{Ba}$ & 4.78Aa & $18.92 \mathrm{Aa}$ & $1.36 \mathrm{Cb}$ \\
\hline & NT5 & $0.44 \mathrm{Ca}$ & $0.15 \mathrm{Ca}$ & $0.29 \mathrm{Aa}$ & 4.19Aa & $15.25 \mathrm{Bab}$ & $1.30 \mathrm{CBb}$ \\
\hline & NT3 & $0.48 \mathrm{Ba}$ & $0.26 \mathrm{Aa}$ & $0.22 \mathrm{Ca}$ & $3.42 \mathrm{BCa}$ & $15.03 \mathrm{Bc}$ & $1.51 \mathrm{Ab}$ \\
\hline & CC9 & $0.48 \mathrm{Bb}$ & $0.25 \mathrm{Aa}$ & $0.23 \mathrm{BCa}$ & $3.52 \mathrm{ABCa}$ & $10.82 \mathrm{Cb}$ & $1.40 \mathrm{Bb}$ \\
\hline & $\mathrm{CC} 5$ & $0.46 \mathrm{BCa}$ & $0.21 \mathrm{Ba}$ & $0.25 \mathrm{Ba}$ & $2.87 \mathrm{Ca}$ & $11.75 \mathrm{Cb}$ & $1.39 \mathrm{Bb}$ \\
\hline \multirow{5}{*}{ 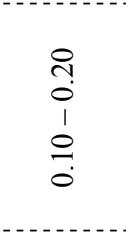 } & $\mathrm{NC}$ & $0.48 \mathrm{Ab}$ & $0.26 \mathrm{Aab}$ & $0.22 \mathrm{BCb}$ & $4.92 \mathrm{Aa}$ & $18.31 \mathrm{Aba}$ & $1.40 \mathrm{Bb}$ \\
\hline & NT5 & $0.40 \mathrm{Bb}$ & $0.12 \mathrm{Db}$ & $0.28 \mathrm{Aa}$ & $3.48 \mathrm{Ba}$ & $16.58 \mathrm{Ba}$ & $1.38 \mathrm{Ba}$ \\
\hline & NT3 & $0.43 \mathrm{Bbc}$ & $0.21 \mathrm{Bb}$ & $0.22 \mathrm{BCa}$ & $2.46 \mathrm{Ca}$ & $19.91 \mathrm{Aa}$ & $1.59 \mathrm{Aa}$ \\
\hline & CC9 & $0.40 \mathrm{Bc}$ & $0.17 \mathrm{Cb}$ & $0.23 \mathrm{BCa}$ & $3.80 \mathrm{Ba}$ & $10.92 \mathrm{Cb}$ & $1.51 \mathrm{Aa}$ \\
\hline & $\mathrm{CC} 5$ & $0.42 \mathrm{Bb}$ & $0.17 \mathrm{BCb}$ & $0.25 \mathrm{Bab}$ & $2.31 \mathrm{Ca}$ & $12.06 \mathrm{Cb}$ & $1.59 \mathrm{Aa}$ \\
\hline \multirow{5}{*}{ 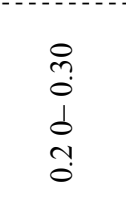 } & $\mathrm{NC}$ & $0.47 \mathrm{Bb}$ & $0.25 \mathrm{~A} b$ & $0.22 \mathrm{ABb}$ & $4.78 \mathrm{Aa}$ & $18.59 \mathrm{Ba}$ & $1.51 \mathrm{Ba}$ \\
\hline & NT5 & $0.39 \mathrm{Cb}$ & $0.16 \mathrm{Ca}$ & $0.23 \mathrm{ABb}$ & $3.09 \mathrm{BCa}$ & $15.48 \mathrm{Cab}$ & $1.40 \mathrm{Ca}$ \\
\hline & NT3 & $0.42 \mathrm{Cc}$ & $0.21 \mathrm{Bb}$ & $0.21 \mathrm{Ba}$ & $2.84 \mathrm{BCa}$ & $17.84 \mathrm{Bb}$ & 1.62Aa \\
\hline & CC9 & $0.51 \mathrm{Aa}$ & $0.27 \mathrm{Aa}$ & $0.24 \mathrm{Aa}$ & $3.79 \mathrm{Ba}$ & $19.29 \mathrm{Ba}$ & $1.54 \mathrm{ABa}$ \\
\hline & $\mathrm{CC} 5$ & $0.41 \mathrm{Cb}$ & $0.18 \mathrm{BCab}$ & $0.23 \mathrm{ABb}$ & $2.29 \mathrm{Ca}$ & $21.86 \mathrm{Aa}$ & $1.30 \mathrm{Dc}$ \\
\hline $\mathrm{CV}(\%)$ & & 4.26 & 8.89 & 6.20 & 19.69 & 18.51 & 5.15 \\
\hline
\end{tabular}

Note. NT5: no till after 5 years; NT3; no-till after 3 years; CC9: conventional till after 9 years; CC5: conventional till after 5 years; NC: Native Cerrado.

Regarding $\mathrm{Tp}$, there was no significant difference between the tillage systems for each soil layer, except for NT5 and CC5 at 0.0-0.10 m and CC9 at 0.20-0.30 m layer (Table 2). The lower Tp values recorded at NT5 may be a result of the influence of the machinery traffic and the non-tillage of the soil (Pragana et al., 2012) causing soil compaction, especially if conducted at high soil moisture content (Guimarães et al., 2013; Servadio et al., 2016). 
Mic values presented an increasing trend with depth for all evaluated systems; except CC5 and NT5. Additionally, were recorded higher proportion of Mic to Mac at deeper layers, which can increase water retention as well as decrease water infiltration into the soil.

The GMD values presented a significant difference between the systems, with highest values recorded at the Native Cerrado site at $0.10-0.20 \mathrm{~m}$ soil layer (mean: $4.92 \mathrm{~mm}$ ). When compared the tillage systems, highest values were recorded at NT5 in the 0.0-0.10 m layer (mean: $4.19 \mathrm{~mm}$ ). At this site, it was observed a reduction of GMD values at deeper soil layers, whereas higher GMD values were observed at deeper soil layers from CC9 (mean: $3.79 \mathrm{~mm}$ at $0.20-0.30 \mathrm{~m}$ soil layer).

Higher GMD values were observed in NT5 compared to NT3 and also CC9 in relation to CC5. At the no-till sites, it cannot be inferred that the adoption age of the conservation practices was sufficient to improve soil structure and physical quality. At the same study site, Pragana et al. (2012) observed a negative effect on soil quality eight years after the implementation no-till system, showing that the evaluation time was not enough to improve soil physical quality. The grain size composition is another factor that may have contributed since NT5 presents lower sand content when compared to NT3 (Table 1).

For each tillage system, GMD values were not significantly influenced by the sampling depth. The lowest GMD value was observed in CC5 $(2.29 \mathrm{~mm})$ at $0.20-0.30 \mathrm{~m}$ soil layer. A comparative analysis shows that GMD is not associated with the TOC contents, showing a certain randomness of the results. Fontenele et al. (2009) reported higher GMD values (GMD $>3.3 \mathrm{~mm}$ ) in a Oxisol conventionally cultivated, which were statistically similar to values recorded at a no-till site. This high stability of aggregates may be due to successive wetting and drying cycles (Wendling et al., 2012) or related to a possible soil compaction.

The highest TOC values were found at the Native Cerrado, mainly in the $0.0-0.10 \mathrm{~m}$ soil layer. The non-mobilization of the soil and the constant deposition of organic material are the main factors that contribute to the higher TOC values recorded for this area (Carneiro et al., 2009; Rossetti \& Centurion, 2015). When compared the tillage systems, the TOC contents were similar for all depths. This fact can result from the remnant of previous conventional tillage when the plowing caused the incorporation of the organic matter in greater depths (Rossetti \& Centurion, 2001).

At the surface layers $(0.0-0.10 \mathrm{~m})$, the Ds values recorded for Native Cerrado and PD5 were statistically similar, differing from the other treatments (NT3, CC5 and CC9) (Table 2). However, the Ds values are considered low to the soil textural class (Sandy clay loam). Additionally, for all tillage systems, an increasing trend for the Ds values was observed towards the $0.10-0.20 \mathrm{~m}$ depth. This trend was also observed for to the $0.20-0.30 \mathrm{~m}$ layer, except in CC5 where a reduction trend was observed. Soil plowing and harrowing increase soil macroporosity, but this beneficial effect is eliminated by soil compaction (Silva et al., 2005).

Regarding the influence of time on management systems, NT5 presented lower Pt and Mac and higher Mic, although these values are not limiting for the development of most agricultural crops. In NT5, an increase of GMD was observed in relation to the other management systems, mainly in the superficial layer.

The clustering analysis indicates the formation of clusters for each soil layers (Figure 1). For the 0.0-0.10 m soil layer, were obtained three distinct groups formed by CC5 and CC9 (i); Native Cerrado (ii); and NT3 and NT5 (iii). The groups were formed according to the similarity between their components, indicating the strong influence of the management system on the soil properties of this layer. 

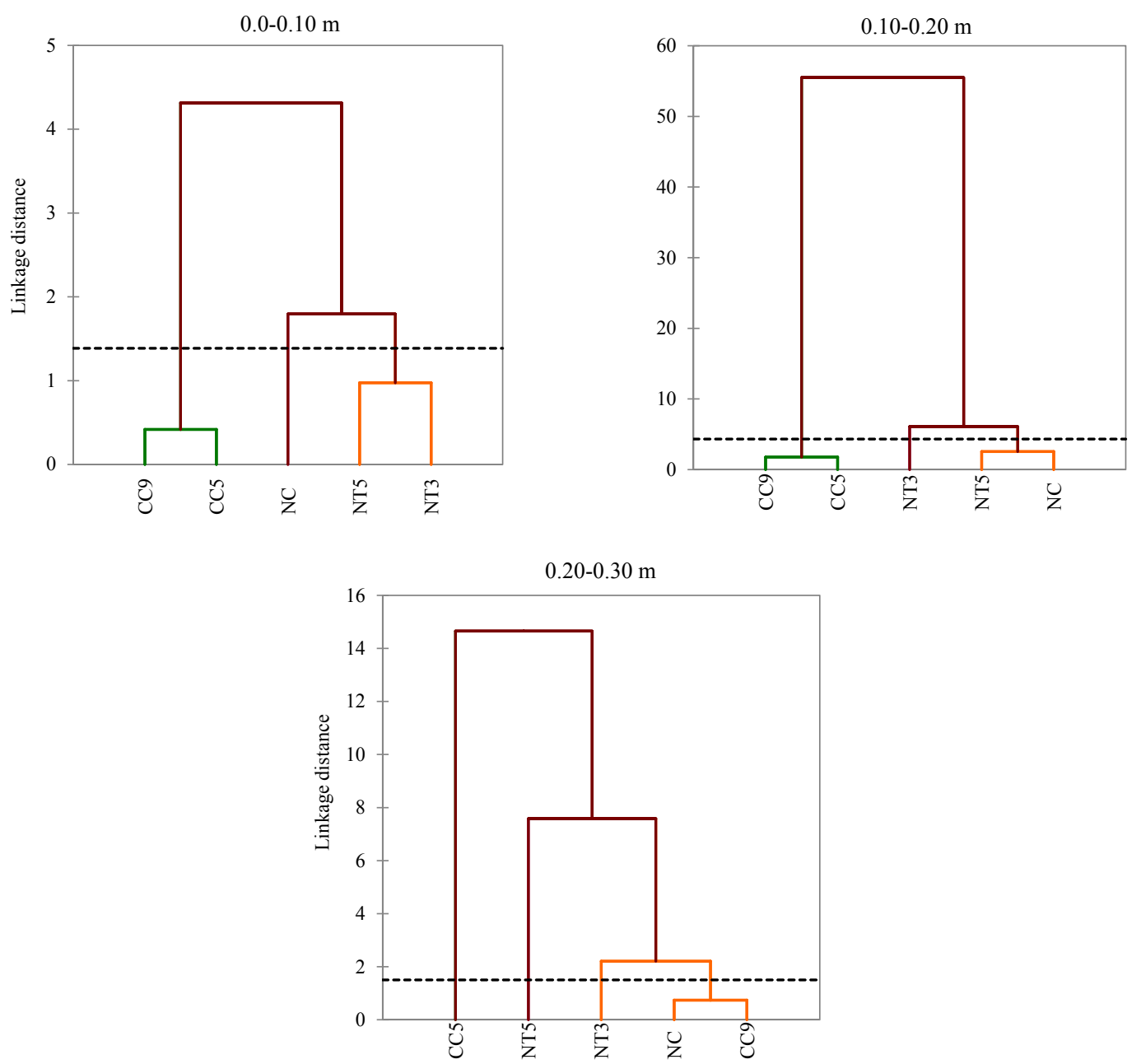

Figure 1. Dendrogram of hierarchical cluster analysis for the tillage systems at different depths

Note. NT5: no till after 5 years; NT3; no-till after 3 years; CC9: conventional till after 9 years; CC5: conventional till after 5 years; NC: Native Cerrado.

In the 0.10-0.20 m layer, only two clusters were observed: a group formed by conventional tillage (CC5-CC9) and second formed by PD3, PD5, and Native Cerrado. For the $0.20-0.30 \mathrm{~m}$ layer, was observed the formation of 4 clusters with similarity observed only among Native Cerrado and CC9.

For the 0.0-0.10 m layer, principal component (PC) 1 and 2 showed eigenvalues greater than 1, explaining 59.7 and $27.6 \%$ of the total variance (Table 4). The PC 1 is mostly represented by the variables Ds, Mic and Pt, whereas PC 2 is formed by GMD (Table 5).

Table 4. Eigenvalues and explained variance by each principal component (PC) for each soil layer

\begin{tabular}{|c|c|c|c|c|c|c|}
\hline \multirow[b]{2}{*}{ Components } & \multicolumn{2}{|c|}{$0.0-0.10 \mathrm{~m}$} & \multicolumn{2}{|c|}{$0.10-0.20 \mathrm{~m}$} & \multicolumn{2}{|c|}{$0.20-0.30 \mathrm{~m}$} \\
\hline & Eigenvalues & $\begin{array}{l}\text { Explained } \\
\text { variability }(\%)\end{array}$ & Eigenvalues & $\begin{array}{l}\text { Explained } \\
\text { variability (\%) }\end{array}$ & Eigenvalues & $\begin{array}{l}\text { Explained } \\
\text { variability }(\%)\end{array}$ \\
\hline 1 & 3.585 & 59.7 & 2.832 & 47.2 & 3.116 & 51.9 \\
\hline 2 & 1.654 & 27.6 & 2.239 & 37.3 & 1.529 & 25.5 \\
\hline 3 & 0.729 & 12.2 & 0.853 & 14.2 & 0.892 & 14.9 \\
\hline 4 & 0.032 & 0.5 & 0.076 & 1.3 & 0.464 & 7.7 \\
\hline
\end{tabular}


Table 5. Factorial loads by main component method for factor composition, after Varimax rotation, for different depths

\begin{tabular}{|c|c|c|c|c|c|c|}
\hline \multirow{2}{*}{ Variable } & \multicolumn{2}{|c|}{$0.0-0.10 \mathrm{~m}$} & \multicolumn{2}{|c|}{$0.10-0.20 \mathrm{~m}$} & \multicolumn{2}{|c|}{$0.20-0.30 \mathrm{~m}$} \\
\hline & Factor 1 & Factor 2 & Factor 1 & Factor 2 & Factor 1 & Factor 2 \\
\hline $\mathrm{Bd}$ & -0.959 & 0.000 & -0.988 & 0.151 & 0.956 & -0.152 \\
\hline GMD & 0.597 & 0.756 & 0.851 & 0.359 & 0.685 & 0.434 \\
\hline TOC & 0.073 & 0.855 & 0.295 & 0.506 & -0.365 & 0.603 \\
\hline Mac & -0.707 & 0.587 & 0.076 & 0.974 & 0.722 & 0.678 \\
\hline Mic & 0.931 & -0.089 & 0.248 & -0.928 & -0.404 & 0.686 \\
\hline $\mathrm{Tp}$ & 0.967 & -0.017 & 0.988 & -0.151 & -0.956 & 0.152 \\
\hline
\end{tabular}

Note. Bulk Density (Bd), Geometric Mean Diameter (GMD), Total Organic Carbon (TOC), Macroporosity (Mac), Microporosity (Mic), and Total Porosity (Tp) for the studied sites.

For the 0.10-0.20 and 0.20-0.30 m layers, PC 1 and 2 presented the same trend, showing eigenvalues $>1$. Regarding the variance for the $0.10-0.20 \mathrm{~m}$ layer, PC 1 and PC 2 represented 47.2 and $37.3 \%$, respectively. The PC 1 was formed by Ds, GMD, and Pt whereas PC 2 was formed by Mac and Mic. For the $0.20-0.30$ m layer, PC 1 and 2 presented 51.9 and $25.5 \%$ of the variance, respectively, formed by Ds and Pt (PC 1); and COT, Mac, and Mic (PC 2).

\section{Conclusions}

Changes in the soil physical properties, which were more evident in the surface layer, were particularly due to the time of the tillage systems implementation. Although better soil physical properties were observed after five years of no-tillage, a longer evaluation time is required for the studied conditions.

Through multivariate analysis, it was observed that soil density, total porosity, macro and microporosity were the variables that achieved the highest percentage of variance among the evaluated tillage systems.

\section{References}

Bavoso, M. A., Giarola, N. F. B., Tormena, C. A., \& Pauletti, V. (2010). Preparo do solo em áreas de produção de grãos, silagem e pastejo: Efeito na resistência tênsil e friabilidade dos agregados. Revista Brasileira de Ciência do Solo, 34, 227-234. https://doi.org/10.1590/S0100-06832010000100023

Betioli Junior, E., Moreira, W., Tormena, C. A., Ferreira, C. J. B., Silva, A. P., \& Giarola, N. F. B. (2012). Intervalo hídrico ótimo e grau de compactação de um Latossolo vermelho após 30 anos sob plantio direto. Revista Brasileira de Ciência do Solo, 36, 971-982. https://doi.org/10.1590/S0100-06832012000300027

Beutler, A. N., Silva, M. L. N., Curi, N., Fereira, M. M., Pereira Filho, I. A., \& Cruz, J. C. (2001). Agregação de Latossolo vermelho distrófico típico relacionada com o manejo na região dos cerrados no estado de Minas Gerais. Revista Brasileira de Ciência do Solo, 25, 129-136. https://doi.org/10.1590/S0100-06832001 000100014

Carneiro, C. E. A., Júnior, N. J. M., Azevedo, M. C. B., Andrade, W. S., Koguishi, M. S., Diehl, R. C., ... Ralisch, R. (2009). Efeitos dos sistemas de manejo sobre o carbono orgânico total e carbono residual de uma Latossolo Vermelho eutroférrico. Semina: Ciências Agrárias, 30, 5-10. https://doi.org/10.5433/1679-0359. 2009v30n1p5

Carneiro, M. A. C., Souza, E. D., Reis, E. F., Pereira, H. S., \& Azevedo, W. R. (2009). Atributos físicos, químicos e biológicos de solo de cerrado sob diferentes sistemas de uso e manejo. Revista Brasileira de Ciência do Solo, 33, 147-157. https://doi.org/10.1590/S0100-06832009000100016

Costa, A., Albuquerque, J. A., Mafra, A. L., \& Silva, F. R. (2009). Propriedades físicas do solo em sistema de manejo na integração agricultura-pecuária. Revista Brasileira de Ciência do Solo, 33, 235-244. https://doi.org/10.1590/S0100-06832009000200001

Farias, M. F., Feitosa, C. E. L., Rodrigues, K. M., Teixeira, L. C., Furtado, M. B., \& Parra-serrano, L. J. (2017). Impact of Management on the Physical Attributes of a Dystrophic Yellow Latosol. Journal of Agricultural Science, 9(5), 217-225. https://doi.org/10.5539/jas.v9n5p217 
Fontana, A., Teixeira, W. G., Balieiro, F. C., Moura, T. P. A., Menezes, A. R., \& Santana, C. I. (2016). Características e atributos de Latossolos sob diferentes usos na região Oeste do Estado da Bahia. Pesquisa Agropecuária Brasileira, 51(9), 1457-1465. https://doi.org/10.1590/s0100-204x2016000900044

Fontenele, W., Salviano, A. A. C., \& Mousinho, F. E. P. (2009). Atributos físicos de um Latossolo Amarelo sob diferentes sistemas de manejo no cerrado piauiense. Revista Ciência Agronômica, 40(2), 194-202.

Freitas, L., Casagrande, J. C., Oliveira, I. A., Souza Junior, P. R., \& Campos, M. C. C. (2014). Análises multivariadas de atributos químicos do solo para caracterização de ambientes. Revista Agro@mbiente, 8(2), 155-164. https://doi.org/10.18227/1982-8470ragro.v8i2.1684

Guimarães, R. M. L., Tormena, C. A., Blainski, E., \& Fidalski, J. (2013). Intervalo hídrico ótimo para avaliação da degradação física do solo. Revista Brasileira de Ciência do Solo, 37, 1512-1521. https://doi.org/10.1590/ S0100-06832013000600008

Hickmann, C., Costa, L. M., Schaefer, C. E. G. R., Fernandes, R. B. A., \& Andrade, C. L. T. (2012). Atributos físico-hídricos e carbono orgânico de um argissolo após 23 anos de diferentes manejos. Revista Caatinga, 25(1), 128-136.

Loss, A., Pereira, M. G., Giácomo, S. G., Perin, A., \& Anjos, L. H. C. (2011a). Agregação, carbono orgânico e nitrogênio em agregados do solo sob plantio direto com integração lavoura-pecuária. Pesquisa agropecuária Brasileira, 46(10), 1269-1276. https://doi.org/10.1590/S0100-204X2011001000022

Loss, A., Pereira, M. G., Schutz, N., Dos Anjos, L. H. C., \& Silva, E. M. R. (2011b). Frações orgânicas e índice de manejo de carbono do solo em diferentes sistemas de produção orgânica. Idesia, 29(2), 11-19. https://doi.org/10.4067/S0718-34292011000200002

Pragana, R. B., Ribeiro, M. R., Nóbrega, J. C. A., Ribeiro Filho, M. R., \& Costa, J. A. (2012). Qualidade física de Latossolos Amarelos sob plantio direto na região do cerrado piauiense. Revista Brasileira de Ciência do Solo, 36(5), 1591-1600. https://doi.org/10.1590/S0100-06832012000500023

Rossetti, K. V., \& Centurion, J. F. (2015). Estoque de carbono e atributos físicos de um Latossolo em cronossequência sob diferentes manejos. Revista Brasileira de Engenharia Agrícola e Ambiental, 19(3), 252-258. https://doi.org/10.1590/1807-1929/agriambi.v19n3p252-258

Santos, D. C., Lima, C. L. R., Kunde, R. J., Carvalho, J. S., Abeijon, L. M., \& Pillon, C. N. (2012). Agregação e proteção física da matéria orgânica em Planossolo Háplico sob diferentes sistemas de manejo. Bioscience Journal, 28(1), 54-63.

Servadio, P., Bergonzoli, S., \& Beni, C. (2016). Soil tillage systems and wheat yield under climate change scenarios. Agronomy, 6(3), 43. https://doi.org/10.3390/agronomy6030043

Silva, A. P., Babujia, L. C., Franchini, J. C., Ralisch, R., Hungria, M., \& Guimarães, M. F. (2014b). M.F. Soil structure and its influence on microbial biomass in different soil and crop management systems. Soil \& Tillage Research, 142, 42-53. https://doi.org/10.1016/j.still.2014.04.006

Silva, C. G., Sobrinho, T. A., Vitorino, A. C. T., \& Carvalho, D. F. (2005). Atributos físicos, químicos e erosão entressulcos sob chuva simulada, em sistemas de plantio direto e convencional. Engenharia Agrícola, 25(1), 144-153. https://doi.org/10.1590/S0100-69162005000100016

Silva, E. N. S., Montanari, R., Panosso, A. R., Correa, A. R., Tomaz, P. K., \& Ferraudo, A. S. (2015). Variabilidade de atributos físicos e químicos do solo e produção de feijoeiro cultivado em sistema de cultivo mínimo com irrigação. Revista Brasileira de Ciência do Solo, 39(2), 598-607. https://doi.org/10.1590/ 01000683 rbcs 20140429

Silva, M. M., Alves, M. C., Sousa, A. P., \& Fernandes, F. C. S. (2009). Plantas de cobertura e sistemas de preparo: impactos na qualidade física de um solo de Cerrado. Revista Ceres, 56(1), 103-111.

Silva, R. L., Matias, S. S. R., Lobato, M. G. R., \& Nóbrega, J. C. A. (2014a). Atributos físicos do solo em diferentes coberturas vegetais na região sul do Piauí. Revista Caatinga, 27(3), 160-168.

Wendling, B., Vinhal-Freitas, I. C., Oliveira, R. C., Babata, M. M., \& Borges, E. N. (2012). Densidade, agregação e porosidade do solo em áreas de conversão do cerrado em floresta de pinus, pastagem e plantio direto. Bioscience Journal, 28(1), 256-265.

Yeomans, J. C., \& Bremner, J. M. (1988). A rapid and precise method for routine determination of organic carbon in soil. Comunications in Soil Science and Plant Analysis, 19(13), 1467-1476. https://doi.org/ $10.1080 / 00103628809368027$ 
Yoder, R. E. (1936). A direct method of aggregate analysis of soils and study of the physical nature of erosion losses. Journal American Society Agronomy, 28, 337-351. https://oi.org/10.2134/agronj1936.000219620 $02800050001 \mathrm{x}$

\section{Copyrights}

Copyright for this article is retained by the author(s), with first publication rights granted to the journal.

This is an open-access article distributed under the terms and conditions of the Creative Commons Attribution license (http://creativecommons.org/licenses/by/4.0/). 